\title{
ARTICLE
}

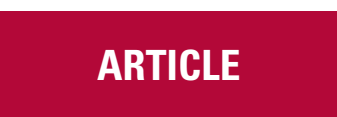

\section{Suicide mitigation: a compassionate approach to suicide prevention ${ }^{\dagger}$}

\author{
Alys Cole-King, Gill Green, Linda Gask, Kevin Hines \& Stephen Platt
}

\begin{abstract}
Alys Cole-King is a consultant liaison psychiatrist in the Betsi Cadwaladr University Health Board and Director of Open Minds Alliance Community Interest Company. She sits on the All-Party Parliamentary Group for Suicide and Self-harm Prevention and is the Royal College of Psychiatrists' spokesperson on suicide and self-harm, also sitting on their Patient Safety Group. She works nationally with medical Royal Colleges, voluntary bodies and academics. Gill Green is Director of the STORM Project, University of Manchester, and Chief Executive of STORM Skills Training Community Interest Company. She has been researching and developing the STORM self-harm mitigation training packages for over 10 years. Linda Gask is Professor of Primary Care Psychiatry at Manchester University. She was co-founder of the STORM

SUMMARY

The death of a patient by suicide can severely affect mental health professionals, particularly if it occurs despite major efforts to intervene. Notwithstanding the difficulties faced by clinicians, suicide prevention remains of paramount importance in order to help save lives. This article seeks to promote a pragmatic and compassionate biopsychosocial response using evidence-based interventions to reduce suicide. It introduces practical strategies that psychiatrists can use in everyday clinical practice, in particular the paradigm shift of suicide mitigation to help prevent suicide. We believe that every encounter with a suicidal person is an opportunity to intervene to reduce their distress and, potentially, to save a life. We believe that it is no longer acceptable for clinicians to state that if patients wish to kill themselves they can do so, in the absence of any attempt at a compassionate intervention.
\end{abstract} training initiative and has carried out research, teaching and clinical work for many years. She works as a psychiatrist with, and provides supervision to, a primary-cared based mental health service in Salford,

Greater Manchester. Kevin Hines survived a serious suicide attempt in 2000. His life is now dedicated to suicide prevention. He has published a book, delivers presentations around the world, and is active in the media and social media to share his inspirational story (www. kevinhinesstory.com). Stephen Platt is Professor of Health Policy Research at the University of Edinburgh, where he was previously Director of the Research Unit in Health, Behaviour and Change. For over 30 years he has pursued a research interest in social, epidemiological and cultural aspects of suicide and self-harm. Correspondence Dr Alys ColeKing, Liaison Team Office, Ablett Unit, Glan Clwyd Hospital, Bodelwyddan, Denbighshire LL18 5UJ, UK. Email: alys.cole-king@wales.nhs.uk

'This is the first of four articles in this issue of Advances discussing suicide. See also pp. 284-291, 292-294, 295-301

\section{DECLARATION OF INTEREST}

A.C.-K. is Director of Open Minds Alliance Community Interest Company and instigator and executive producer of the U Can Cope film. A.C.-K., G.G. and L.G. have received funding to develop and deliver Connecting with People training and to develop the community version of Emotional CPR training (Connecting with People/STORM joint project). G.G. and L.G. have received funding to develop and deliver STORM training.

Suicide risk assessment and management are of significant importance in reducing the likelihood of a completed suicide. Psychiatrists have a responsibility to all patients experiencing suicidal thoughts, regardless of the presence of mental illness. A patient contemplating suicide, or one who has tried to take their life, will at the very least be experiencing personal distress that needs respectful consideration. Failure to treat these patients with understanding and compassion is likely to have a detrimental impact on their mental state (Hawton 2009). Therefore, clinicians should routinely ask patients with depression or emotional distress about thoughts of suicide and self-harm and suicidal behaviour (Cole-King 2011).
The prediction of suicide is fraught with difficulty, and the level of accuracy is likely to be very low - a situation that leaves some clinicians feeling resigned to the futility of any actions taken to help keep a person safe (National Confidential Inquiry into Suicide and Homicide by People with Mental Illness 2010; Cole-King 2013, this issue). Consequently, it is prudent to take all suicidal thoughts with complete seriousness.

Evidence also tells us that increasing hopefulness, resilience and reasons for living reduces the suicide risk (McLean 2008). It is therefore proposed that the only safe response is to adopt a suicide mitigation approach (Cole-King 2010). Suicide mitigation is an active process to try to prevent suicide. It starts from the assumption that suicidal thoughts need to be taken seriously and met with compassion and understanding on every occasion in order to engage positively with the person. For the many suicidal individuals ambivalent about their wish to die, compassionate engagement can be the tipping point back to safety.

\section{The importance of compassion}

Undertaking a suicide risk assessment is potentially life-saving, but the clinical encounter is utterly dependent on what the patient chooses to reveal or keep hidden. In making a 'diagnosis' of suicide risk, clinicians rely on their patients to trust them with often painful and difficult disclosure of their suicidal thoughts. The importance of such disclosure must not be underestimated; in itself, it can be a protective factor (Cole-King 2010, 2011).

A compassionate approach is by far the most useful interaction for positive engagement with a patient. Healthcare professionals who are empathetic and compassionate encourage increased disclosure by patients about concerns, symptoms and behaviour, and are ultimately more effective at delivering care (Larson 2005). Conversely, negative reactions can cause a patient to feel that the clinician is hostile, unsympathetic and uncaring, putting the therapeutic relationship at risk (Thompson 2008). For example, negative reactions among healthcare professionals to selfharming behaviour are common (Royal College of Psychiatrists 2010), and typically result from 
helplessness about making a difference (Taylor 2009). This leads to frustration and/or resentment towards the patient. Suicidal patients have welltuned 'radar', which can detect a clinician's disinterest. This kind of reaction is detrimental to the patient's immediate safety and longer-term recovery (Royal College of Psychiatrists 2010).

Compassionate care must also be competent care, and the establishment of a therapeutic alliance and trusting relationship between clinician and patient must be matched by a comprehensive and skilled risk assessment.

\section{How and when to ask about suicidal thoughts}

Research shows that suicidal thoughts are often not documented in routine assessments (Malone 1995). Appraisal of suicide risk requires a biopsychosocial assessment of the patient, including details of their suicidal thoughts, intent, plans, personal and demographic risk factors and a comprehensive mental state examination. Clinicians can also gain useful and important information from third parties such as family, friends and colleagues, in addition to objective evidence - particularly if someone has self-harmed or attempted suicide. Ultimately, it is first-hand accounts that clinicians need from their patients. A thorough and accurate risk assessment should form the foundation of a multidisciplinary suicide mitigation plan. In addition, it informs a patient's own immediate safety plan, created collaboratively with their clinician, which they can use to increase their resilience to suicidal thoughts.

Suicide risk is determined by thoughts of death (suicidal intent), hopelessness, the methods considered, development of a plan (the degree and seriousness of that intent), risk factors and 'red flag' warning signs. Box 1 gives an overview of the Cole-King Continuum, a clinical tool developed to support a structured professional judgement approach to suicide risk assessment. It was designed to uncover and tease out all of the various aspects of suicidal thoughts and obtain a detailed understanding of very complex and often distressing thoughts.

The questions posed should be clear and direct, leaving no room for misunderstanding. Suicidal thoughts are often ambiguous in nature and may also change rapidly. The distress felt, however, remains constant and critical, needing only a catalyst for the suicide risk to worsen. Through engagement and collaboration with the individual, an early warning safety plan can be developed that identifies potential triggers and appropriate support.
BOX 1 Guidance for clinicians on comprehensive assessment of suicidal thoughts

Suicide intent lies on a continuum from fairly common, vague, passive suicidal thoughts to rarer, high-intent/high-lethality suicidal acts. Some people find it hard to talk about their suicidal thoughts and may initially be reluctant to share them with you. Be aware of your own and the potentially suicidal person's voice and body language. If the patient delays in responding or if their response to a question is simply 'Alright' or 'OK', it might indicate that perhaps the patient is not quite as 'alright' as they claim. If you establish that a patient is experiencing suicidal thoughts, you need to ask further questions to gain as much information as possible.

After each answer, respond with appropriate compassion and then move on to the next step. Be mindful that the way you ask about suicidal thoughts, including responding with compassion, is just as important as the words and phrases you use.

All aspects of suicidal thoughts need to be identified:

- Perception of the future and any hopelessness

- Nature of the suicidal thoughts, i.e. frequency, intensity, persistence, getting worse, etc.

- Degree of suicide intent:

Have they planned and prepared for a suicide attempt?

Have they put their affairs in order?

How detailed is the plan: have they thought about when, where and how; have they considered measures to prevent anyone from finding out about their possible attempt?

- Ability to resist acting on their thoughts of suicide or self-harm

- Whether they have told anyone else about their suicidal thoughts

- Whether they have access to the method they intend to use. If they do, try to disable their plan and remove their access to means.

(Based on the Cole-King Continuum. Copyright @ 2009 Alys Cole-King/ Open Minds Alliance Community Interest Company)

The Cole-King Classification of Suicidal Thoughts (Cole-King 2011), an assessment tool for clinicians, was developed to encourage a common culture and consistency of approach (Table 1). Using a standardised language permits greater clarity, accuracy and consistency of practice over time and across patient groups. Communication is improved between people experiencing suicidal thoughts and those working to help them, including healthcare professionals, their carers and the third (voluntary) sector. This clinical resource forms part of the Connecting with People suicide awareness training $^{\mathrm{a}}$ (Cole-King 2011).

\section{Risk factors}

The clinician should be familiar with established risk factors and risk groups for suicide at a population level, but should not rely wholly on this knowledge when assessing risk in specific individuals. Table 2 gives a comprehensive and clinically relevant overview of all evidence-based risk factors for suicide, including 'red flag' warning signs.

The World Health Organization's World Mental Health Survey Initiative studied 84850 people from the general population in 28 countries to a. The Connecting with People training forms part of the RCPsych education programme, the BMJ Masterclass and the Royal College of General Practitioners accredited Primhe Diploma in Mental Health 
TABLE 1 The Cole-King Classification of Suicidal Thoughts

\begin{tabular}{|c|c|c|c|c|}
\hline & Passive & Active & Dangerous & Dangerous and imminent \\
\hline $\begin{array}{l}\text { Nature of suicidal } \\
\text { thoughts }\end{array}$ & $\begin{array}{l}\text { Infrequent, mild, slow onset, } \\
\text { fleeting, to escape distress, } \\
\text { easy to ignore } \\
\text { Cause little distress }\end{array}$ & $\begin{array}{l}\text { Conscious awareness, } \\
\text { increasing in frequency, } \\
\text { intensity or persistence } \\
\text { Starting to have difficulty } \\
\text { in generating positive } \\
\text { thoughts about the future } \\
\text { Cause increasing distress }\end{array}$ & $\begin{array}{l}\text { Frequent/persistent/intense } \\
\text { and/or } \\
\text { increasingly compelling } \\
\text { Starting to focus on them to } \\
\text { the exclusion of other more } \\
\text { optimistic thoughts } \\
\text { Very hard to generate any } \\
\text { positive thoughts about the } \\
\text { future }\end{array}$ & $\begin{array}{l}\text { Frequent/persistent/intense } \\
\text { Almost 'fascinated' by them and know } \\
\text { they will succumb } \\
\text { Impossible to generate any positive } \\
\text { thoughts about the future } \\
\text { Unable to distract themselves from these } \\
\text { thoughts } \\
\text { Unable to entertain any other thoughts } \\
\text { Omnipotent and compelling }\end{array}$ \\
\hline Perception of future & $\begin{array}{l}\text { Life is difficult but know } \\
\text { they have a future, hope } \\
\text { situation will resolve } \\
\text { Coping with the emotional } \\
\text { pain }\end{array}$ & $\begin{array}{l}\text { Life is very difficult } \\
\text { Future difficult } \\
\text { Hard to see an end to } \\
\text { situation } \\
\text { May still have some hope } \\
\text { and is coping with the } \\
\text { emotional pain }\end{array}$ & $\begin{array}{l}\text { Life is a struggle } \\
\text { Struggling to see a future } \\
\text { Unable to see an end to } \\
\text { situation } \\
\text { Little or no hope } \\
\text { Emotional pain almost } \\
\text { unbearable }\end{array}$ & $\begin{array}{l}\text { Life is impossible } \\
\text { No future } \\
\text { Suicide only option } \\
\text { Unable to see beyond today } \\
\text { Extreme hopelessness } \\
\text { Emotional pain totally unbearable }\end{array}$ \\
\hline $\begin{array}{l}\text { Degree of planning } \\
\text { of suicidal act }\end{array}$ & $\begin{array}{l}\text { Suicide not an option, } \\
\text { no thoughts concerning } \\
\text { planning }\end{array}$ & $\begin{array}{l}\text { Conscious thoughts } \\
\text { regarding theoretical } \\
\text { methods but no active } \\
\text { planning }\end{array}$ & $\begin{array}{l}\text { Conscious awareness of } \\
\text { planning of method }\end{array}$ & $\begin{array}{l}\text { Planning complete } \\
\text { Likely to have chosen a potentially lethal } \\
\text { method } \\
\text { May have a date and venue etc }\end{array}$ \\
\hline $\begin{array}{l}\text { Degree of } \\
\text { preparation }\end{array}$ & $\begin{array}{l}\text { None, as suicide is not an } \\
\text { option }\end{array}$ & $\begin{array}{l}\text { None, as suicide is not an } \\
\text { option }\end{array}$ & $\begin{array}{l}\text { Actively seeking means } \\
\text { Sorting affairs }\end{array}$ & $\begin{array}{l}\text { Means obtained } \\
\text { Affairs in order }\end{array}$ \\
\hline Ability to resist & $\begin{array}{l}\text { Very easy to resist } \\
\text { Absolute belief will not act } \\
\text { on thoughts }\end{array}$ & Able to resist & $\begin{array}{l}\text { Concerns regarding ability } \\
\text { to resist and fears for own } \\
\text { safety }\end{array}$ & Unable to resist \\
\hline $\begin{array}{l}\text { Response required } \\
\text { (this will depend on } \\
\text { clinical need, local } \\
\text { services, access } \\
\text { to lethal means, } \\
\text { support available } \\
\text { and advice via NICE } \\
\text { guidelines) }\end{array}$ & $\begin{array}{l}\text { Empathy and optimism } \\
\text { Instil hope and uncover } \\
\text { reasons for living } \\
\text { Create a simple safe } \\
\text { plan, including third } \\
\text { sector support to increase } \\
\text { resilience } \\
\text { Remove means } \\
\text { Provide U Can Cope and } \\
\text { 'Feeling overwhelmed' } \\
\text { resources } \\
\text { Maximise family and social } \\
\text { support } \\
\text { Perform social support } \\
\text { mapping }\end{array}$ & $\begin{array}{l}\text { Empathy, optimism } \\
\text { Instil hope and uncover } \\
\text { reasons for living } \\
\text { Triage to assess whether } \\
\text { safe to review in 1-2 days } \\
\text { May require a mental } \\
\text { health referral if they } \\
\text { have a mental illness } \\
\text { Robust safety plan } \\
\text { including remove means } \\
\text { Ensure adequate support: } \\
\text { provide } U \text { Can Cope and } \\
\text { 'Feeling overwhelmed' } \\
\text { resources } \\
\text { perform social support } \\
\text { mapping }\end{array}$ & $\begin{array}{l}\text { Empathy, optimism } \\
\text { Instil hope and uncover } \\
\text { reasons for living } \\
\text { Triage to assess whether } \\
\text { safe to review tomorrow } \\
\text { and whether requires } \\
\text { referral to mental health } \\
\text { services } \\
\text { Robust safety plan, } \\
\text { including remove means } \\
\text { Ensure adequate support: } \\
\text { provide } U \text { Can Cope and } \\
\text { 'Feeling overwhelmed' } \\
\text { resources }{ }^{\text {b }} \\
\text { perform social support } \\
\text { mapping }\end{array}$ & $\begin{array}{l}\text { If immediate risk of suicide, urgent } \\
\text { intervention is required } \\
\text { Empathy and compassion, authentic } \\
\text { optimism } \\
\text { Instil hope and start to uncover reasons } \\
\text { for living } \\
\text { Remove means } \\
\text { Immediate discussion of case, with a } \\
\text { possible referral to specialist mental } \\
\text { health services } \\
\text { If immediate risk, and especially if } \\
\text { patient is unknown to practitioner, } \\
\text { they will require robust safe plan and } \\
\text { immediate referral: without these, the } \\
\text { patient is highly likely to try to end } \\
\text { their life }\end{array}$ \\
\hline
\end{tabular}

a. Bold denotes particularly important actions.

b. The U Can Cope film is available at www.connectingwithpeople.org. Feeling overwhelmed - helping you stay safe' is available from the Royal College of Psychiatrists, online or as printed leaflets (www.rcpsych.ac.uk/mentalhealthinfoforall.aspx). For further details see Hines 2013: Box 1 (this issue)

Note For patient safety, this clinical tool should be used only by someone who has received appropriate training from a licensed Connecting with People trainer and only as part of a full clinical assessment. It is not intended to replace clinical judgement and is to be used within a full clinical assessment.

Copyright (C) 2010 Alys Cole-King/Open Minds Alliance Community Interest Company. Published with kind permission of Open Minds Alliance Community Interest Company.

identify any association between suicidal thoughts and plans and suicidal behaviour. It found that $29 \%$ of people with suicidal thoughts went on to make a suicide attempt, usually within a year of onset of the thoughts (Nock 2008). If those people who were experiencing suicidal thoughts also had a well-formed plan they were far more likely to engage in suicidal behaviour:

- across all countries, $60 \%$ of transitions from ideation to plan and attempt occurred within the first year after ideation onset

- individuals with a suicide plan had a 56\% probability of making a 'suicide attempt'
- individuals without a suicide plan had a $15.4 \%$ probability of a 'suicide attempt'.

Thus, a person may be at high risk of suicide even if they do not belong to one of the groups in Table 2 . Conversely, not all members of high-risk groups are equally at risk of suicide. Moreover, suicidal thoughts (and risk) can vary across a relatively short time period. The assessment of suicide risk by the clinician needs to be individually focused and carried out on a regular basis.

The strongest risk factor for acting on suicidal thoughts in high-income countries was a mood disorder, particularly if accompanied by substance 


\begin{tabular}{|c|c|c|c|}
\hline Demographic and social & Personal background & Clinical factors in history & $\begin{array}{l}\text { Mental state examination and 'red } \\
\text { flag' warning signs }\end{array}$ \\
\hline $\begin{array}{l}\text { Demographic factors } \\
\text { Gender and age: male, younger men } \\
\text { and very elderly (but recent increase in } \\
\text { middle-aged men) } \\
\text { Marital status: separated > divorced > } \\
\text { widowed > single > married } \\
\text { Unemployment: initially high risk, } \\
\text { decreases after } 3 \text { months until after } \\
\text { about } 1 \text { year, then higher again } \\
\text { Profession: farmers, veterinarians, } \\
\text { doctors (female) and dentists } \\
\text { Economic class (high and low income) } \\
\text { Ethnic group: minorities (e.g. Black or } \\
\text { Asian women); refugees }\end{array}$ & $\begin{array}{l}\text { Family history } \\
\text { Suicide } \\
\text { Mental illness, particularly alcoholism } \\
\text { and bipolar affective disorder }\end{array}$ & $\begin{array}{l}\text { Current mental illness } \\
\text { Repeated relapses, recent admission/ } \\
\text { discharge from psychiatric unit; recent } \\
\text { relapse in mental illness } \\
\text { Self-neglect } \\
\text { Agitation } \\
\text { Depressive symptoms, especially } \\
\text { anhedonia and insomnia } \\
\text { Severe anxiety and panic } \\
\text { Post-traumatic stress disorder }\end{array}$ & $\begin{array}{l}\text { Hopelessness } \\
\text { Perception of the future as } \\
\text { persistently negative and hopeless: } \\
\text { of particular concern if only able to } \\
\text { see 1-2 hours into future } \\
\text { Negative thoughts, helplessness, } \\
\text { guilt, 'I'm a burden', 'nothing to } \\
\text { live for' } \\
\text { Sense of 'entrapment' } \\
\text { Sense of shame, especially if } \\
\text { severe and/or if in conflict with } \\
\text { underlying religious or spiritual } \\
\text { beliefs }\end{array}$ \\
\hline $\begin{array}{l}\text { Life events } \\
\text { Significant threat or loss, e.g. health } \\
\text { event, bereavement of partner or close } \\
\text { family } \\
\text { Childhood adversity } \\
\text { No memory of being special to any } \\
\text { adult when growing up } \\
\text { Bullying or abuse } \\
\text { Relationship instability } \\
\text { Redundancy } \\
\text { Unemployment }\end{array}$ & $\begin{array}{l}\text { Personality disorder } \\
\text { Personality traits of impulsivity, } \\
\text { aggression, lability of mood } \\
\text { Sudden unexplained changes in } \\
\text { behaviour or uncharacteristic } \\
\text { behaviour }\end{array}$ & $\begin{array}{l}\text { Previous self-harm } \\
\text { Especially high-suicide-intent attempt, } \\
\text { superficial cutting, recent increasing intent } \\
\text { of repeated self-harm } \\
\text { The risk of a completed suicide remains } \\
\text { raised for many years after a high-suicide- } \\
\text { intent act }\end{array}$ & $\begin{array}{l}\text { Suicidal ideas and plans } \\
\text { Especially if omnipotent and } \\
\text { compelling, recently worsened and } \\
\text { associated with distress } \\
\text { Suicide plans/preparations, e.g. } \\
\text { will, goodbye note/text/email, } \\
\text { internet search for methods; } \\
\text { lethality of method; possible rescue/ } \\
\text { treatment } \\
\text { Unable to distract themselves from } \\
\text { suicidal thoughts } \\
\text { Note: The method can easily } \\
\text { change from low to high lethality }\end{array}$ \\
\hline $\begin{array}{l}\text { Social capital (lack of) } \\
\text { Social isolation and living alone } \\
\text { Recent loss of attachment } \\
\text { Perception of lack of social support/ } \\
\text { confidants } \\
\text { Institutionalisation, e.g. prison } \\
\text { Recently leaving armed forces } \\
\text { Major relationship instability } \\
\text { Recently bereaved } \\
\text { Loss of privilege } \\
\text { Use of suicide-promoting websites }\end{array}$ & $\begin{array}{l}\text { Substance misuse } \\
\text { Precipitated by loss of interpersonal } \\
\text { relationships } \\
\text { Especially if: } \\
\text { high level of dependency; } \\
\text { long history of drinking; } \\
\text { binge drinking; } \\
\text { depressed mood; } \\
\text { poor physical health; } \\
\text { poor work record in past } 4 \text { years } \\
\text { (peak age } 40-60 \text { years) }\end{array}$ & $\begin{array}{l}\text { Chronic medical illness } \\
\text { (1 in } 10 \text { of completed suicides) } \\
\text { Especially if accompanied by chronic } \\
\text { pain, functional disability or incurable } \\
\text { Cancer; cardiovascular disease; dialysis; } \\
\text { gastrointestinal disease; genitourinary } \\
\text { disease in men; epilepsy (especially early } \\
\text { onset); multiple sclerosis; dementia; } \\
\text { neurological illness after cerebral trauma }\end{array}$ & $\begin{array}{l}\text { Psychotic phenomena } \\
\text { Distressing phenomena, } \\
\text { persecutory delusions, nihilistic } \\
\text { delusions; command hallucinations } \\
\text { perceived as omnipotent } \\
\text { Cognitive functioning } \\
\text { Delirium } \\
\text { Low IO }\end{array}$ \\
\hline $\begin{array}{l}\text { Access to lethal means } \\
\text { Firearms } \\
\text { Poisons (available to, e.g., dentists, } \\
\text { farmers, anaesthetists) } \\
\text { Suicide 'hot spots' }\end{array}$ & $\begin{array}{l}\text { Poor problem-solving skills } \\
\text { Low IO } \\
\text { Poor coping skills }\end{array}$ & $\begin{array}{l}\text { Medication } \\
\text { Over-the-counter and prescribed (consider } \\
\text { issuing weekly prescriptions) } \\
\text { Note the additive effect of different } \\
\text { medications }\end{array}$ & $\begin{array}{l}\text { Insight } \\
\text { High premorbid functioning and fear of } \\
\text { deterioration } \\
\text { Early stage of illness }\end{array}$ \\
\hline
\end{tabular}

a. Bold denotes 'red flag' warning signs which need to be taken particularly seriously.

Source: Cole-King 2010. Reproduced, with updates and amendments, by kind permission of the British Journal of General Practice.

misuse or stressful life events. Impulsivity alone did not predict suicide, but may have increased the risk of a patient acting on suicidal thoughts.

\section{The practicalities of suicide mitigation and developing a safety plan}

The more clinicians understand about the nature of suicidal thoughts, the more they will be able to empower patients not to act on them. Some individuals have recurrent, chronic or intractable suicidal thoughts. Others experience a unique pattern of thoughts and impulses as they progress towards a suicide attempt - their 'crisis signature'.
Patients can be helped to monitor these thoughts, to recognise their 'danger points' and to seek support before they engage in self-harm or attempt suicide.

Compassionate care forms the bedrock of the collaborative creation of a safety plan. The clinician needs to invest time in listening to, and engaging with, the patient, exploring reasons for living, developing strategies to help keep them safe and establishing a network of support. The safety plan is patient-centred and personalised. Its aim is to help keep the patient safe now and in the future by connecting them with people at home 
and in the community. A multifaceted approach to treatment and care is encouraged, as this provides greater success in safety planning. Even when the underlying disorder prompting suicidal thoughts has a primarily biological aetiology, psychosocial interventions can also help. Table 3 presents an overview of possible biopsychosocial suicide mitigation strategies.

The key to a compassionate suicide mitigation approach is the emphasis on collaboration rather than direction. The patient should feel comfortable with their safety plan and agree to the interventions detailed in it, particularly provision for access to out-of-hours support, when people are often at their most vulnerable. Note that an immediate safety plan will depend on the seriousness of a person's suicidal thoughts and planning, along with their ability to delay a possible suicidal act the presence of protective factors. The more serious the suicidal thoughts and planning and the greater the lack of protective factors, the more the clinician will need to 'direct' rather than 'co-create' support to keep the patient safe. In this situation, support is more likely to include professional intervention, with a possible admission to hospital. Once the crisis has dissipated, however, a longer-term, suicide mitigation safety plan can be created in collaboration with the patient to help deal with any future crisis.

By encouraging and empowering patients to take back responsibility for staying safe, the clinician instils a sense of self-efficacy and personal control and enhances resilience. This is important if a safety plan is to halt a suicidal act in the future. Furthermore, discussing events and triggers responsible for causing emotional distress is an important transition on the road to recovery. It is a firm belief of Kevin Hines, a survivor of suicide, that one may never be fully recovered from a severe and enduring mental illness, particularly after a high-intent, high-lethality suicide attempt, but that one is always 'in recovery' (Hines 2013, this issue, pp. 292-294).

It is also important to build a network of support that can be mobilised in the event of a crisis. This might include both personal contacts and third-sector organisations (for a list of UKbased organisations, see Box 1 in Hines 2013, this issue). From this network a 'key contact' should be identified. This is likely to be someone from their immediate circle of family and friends with whom the patient feels comfortable and

\section{TABLE 3 The Cole-King Mitigation Framework: biopsychosocial suicide mitigation strategies}

\begin{tabular}{|c|c|c|c|}
\hline & Biological & Psychological & Social \\
\hline Immediate & $\begin{array}{l}\text { Symptomatic relief } \\
\text { Optimise treatment of any mental illness } \\
\text { Optimise treatment of any medical illness, } \\
\text { especially pain }\end{array}$ & $\begin{array}{l}\text { Non-judgemental, compassionate, person-centred } \\
\text { relationship with practitioner } \\
\text { Validate distress } \\
\text { Optimise protective factors, e.g. authentic optimism, } \\
\text { hope } \\
\text { Use Bank of Hope (see Box 2) and enhance or uncover } \\
\text { reasons for living } \\
\text { Increase resilience and empower the individual to } \\
\text { resist suicidal thoughts } \\
\text { Provide RCPsych resources: 'a 'Feeling overwhelmed - } \\
\text { helping you stay safe'; 'Feeling on the edge? Helping } \\
\text { you get through it' (if after self-harm) }\end{array}$ & $\begin{array}{l}\text { Immediate crisis management } \\
\text { Consider in-patient treatment if no available } \\
\text { support } \\
\text { Consider use of Mental Health Act } \\
\text { Optimise social support } \\
\text { Collaboratively develop and implement safety } \\
\text { plan, including emergency contacts } \\
\text { Remove lethal means if possible; if not } \\
\text { possible use Bank of Hope techniques } \\
\text { Speedy and regular review }\end{array}$ \\
\hline Long term & $\begin{array}{l}\text { Optimise treatment of any mental or physical } \\
\text { illness, review diagnosis } \\
\text { Increase concordance with medication and } \\
\text { identify reasons for reduced concordance } \\
\text { Review medication: } \\
\text { correct treatment } \\
\text { side-effects } \\
\text { effective dose } \\
\text { Consider a different medication if genuine } \\
\text { reasons for poor concordance } \\
\text { Enhance physical well-being } \\
\text { Encourage physical activity } \\
\text { 'Emergency medication pack' for immediate } \\
\text { treatment of relapse if known mental illness } \\
\text { and appropriate }\end{array}$ & $\begin{array}{l}\text { Increase engagement with services if required } \\
\text { Set clear boundaries where required; this may } \\
\text { necessitate multidisciplinary professional meetings } \\
\text { Maximise therapeutic relationship } \\
\text { Enhance coping/problem-solving skills } \\
\text { Build own Bank of Hope } \\
\text { Recognise own 'crisis signature' } \\
\text { Regular self-monitoring using Cole-King Continuum } \\
\text { Deal with any losses, e.g. via third-sector bereavement } \\
\text { services } \\
\text { Deal with any long-standing problems such as abuse } \\
\text { Enhance mental well-being } \\
\text { Psychotherapy if indicated } \\
\text { Build up resilience, e.g. attend courses such as expert } \\
\text { patient programmes or emotional resilience training } \\
\text { Early intervention for relapse if known mental illness }\end{array}$ & $\begin{array}{l}\text { Consider care programme approach } \\
\text { Enhance social relationships } \\
\text { Enhance family relationships } \\
\text { Consider third sector (e.g. Relate) for } \\
\text { relationship problems } \\
\text { Physical activity } \\
\text { Employment/meaningful activity } \\
\text { Hobbies/socialisation } \\
\text { Lifestyle changes if indicated } \\
\text { Look at ways to reduce stress and conflict }\end{array}$ \\
\hline
\end{tabular}

a. These resources are available from the Royal College of Psychiatrists, online or as printed leaflets (www.rcpsych.ac.uk/mentalhealthinfoforall.aspx).

Note: For patient safety, this clinical tool should be used only by someone who has received appropriate training from a licensed Connecting with People trainer and only as part of a full clinical assessment. Developed by Alys Cole-King and Peter Lepping. Copyright (C 2009 Alys Cole-King/Open Minds Alliance Community Interest Company. Published with kind permission of Connecting with People training, Open Minds Alliance Community Interest Company. 
who is able (and agrees) to provide support if the patient becomes suicidal and feels unable to keep safe. The key contact is a personal resource who acts on behalf of the patient in certain agreed situations. For example, the key contact might attend appointments when the patient is beginning to feel unwell, providing support for the patient and helping with continuity of care. Kevin Hines calls these people his 'personal protectors' and has followed such a safety plan for many years (www. kevinhinesstory.com). Members of his network of support have a 'mental health emergency binder', which he created for just such a purpose, i.e. in a mental health emergency, when he is overwhelmed by suicidal thoughts or finds himself in a troubling situation.

\section{The Bank of Hope}

In addition to identifying risk factors, clinicians should focus on promoting protective factors such as hopefulness, personal resilience and reasons for living. Meaning and purpose in life are individualistic and possible for all humans (Jobes 2011). Even a brief psychological intervention with contact may be effective in reducing subsequent suicide mortality (Fleischmann 2008). The Bank of Hope (Box 2) is a set of simple coping strategies designed to promote resilience and to decrease the seriousness of distress felt by individuals in emotional and physical pain (Cole-King 2011). The strategies are designed to instil hope, enhance the self-efficacy and internal locus of control of a suicidal person, and reduce the potency of suicidal thoughts and the likelihood of acting on them.

The Bank of Hope strategies have been developed as an adjunct to treatment as usual. A comprehensive history, mental state assessment and treatment plan are still required. The key is helping patients to think about their reasons for living and to find cognitive and/or physical cues to promote hopefulness. For example, patients are asked to remember how they feel when they are not suicidal. Clinicians should never presume that they know what these cues are. The safety plan uses tangible reminders and cues: patients' own reasons for living and strategies they have rehearsed to deal with their distress.

It is important to note that the Bank of Hope strategies are not always effective in reducing distress or empowering patients not to act on their suicidal thoughts. If this approach appears not to be working for the patient, they may be at an even greater risk than first thought. In this situation, the Bank of Hope strategies can be used as a 'diagnostic aid' to discriminate between degrees of distress and immediacy of suicide risk.

\section{B0X 2 Therapeutic strategies from the Cole-King Bank of Hope}

Maximise the power of the individual not to act on their suicidal thoughts

- Increase resilience - enhance protective factors.

- Increase internal locus of control - 'Do not be a passive victim of suicidal thoughts'.

- Increase self-efficacy - uncover or teach the skills and techniques not to act on suicidal thoughts.

- Increase emotional resourcefulness and share simple problem-solving techniques to better equip them to deal with their triggers for suicidal thoughts or adverse life events should these occur/continue.

Reduce the power of suicidal thoughts

- Help the individual see that such intense suicidal thoughts do not last forever.

- Intense suicidal feelings are often short lived (although acknowledge that individuals may have intermittent but long-lasting low-grade suicidal thoughts, which can still be very distressing).

- Share examples of others who made serious and potentially lethal suicide attempts but who changed their mind immediately before or halfway through Explain that they realised that they did not want to actually die - they had just felt so desperate and hopeless that they did not know what else to do to make those feelings go away. Their real wish was to feel better, not to die.

- Minimise and devalue the power of the individual's suicidal thoughts, while acknowledging and validating the distress they can cause to them.

- Help the individual to view their suicidal thoughts as nothing more than a symptom of their distress (like having a temperature due to a viral illness), rather than some powerful magical impulse that they cannot resist.

\section{Collaborate to develop a safety plan}

- This will be directed by the patient and facilitated by the clinician; generally, it will consist of tangible reminders of the patient's reasons for living, i.e. names, photos, etc.

(Copyright (c) 2009 Alys Cole-King/Open Minds Alliance Community Interest Company)

Bank of Hope strategies can be further enhanced by the use of some simple solution-focused techniques (Box 3).

\section{BOX 3 A solution-focused therapy approach}

Solution-focused interviewing can help people construct realistic and workable solutions to their problems. Words with a positive connotation (e.g. 'good', 'success' and 'solution') can be more helpful in building a sense of hopefulness and/ or self-efficacy than those with negative connotations (e.g. 'bad', 'failure' and 'problem').

People rarely seem able to resist presuppositions, which may be defined as implicit, unconscious suggestions. These work away at a deep level within them and can promote a sense of self-efficacy and encourage future-oriented thinking. Presuppositional open questions that are affirming and empowering can help a patient to stop the progression of their suicidal thinking and planning. For example:

'How did you cope with previous difficult/ distressing situations?'
'How have you coped with this situation up to now?'

'When you are feeling just a little more optimistic, what thoughts about the future might you be having?'

'When you look back on this testing period in your life, what do you think the main thing that got you through it will have been?'

A powerful question to ask a suicidal person at first interview is the (adapted) 'miracle question':

'Just suppose when you go home tonight. . you go to bed... go to sleep.... miracle happens... and all these strong suicidal feelings and ideas are gone. Only you won't know this miracle has happened, as you are asleep at the time. When you wake up in the morning, what will let you know that the miracle has happened? What will be the first thing you will notice?' (Adapted from Henden 2008: pp. 141-3) 
EMI answers

$1 \mathrm{f} \quad 2 \mathrm{c} \quad 3 \mathrm{f} \quad 4 \mathrm{~g}$
It is also important to note that if patients are experiencing extreme emotional pain and anguish, they may not be able to identify any reasons for living. They may also feel that they are a 'burden' to their family and that they would be 'better off dead'. They may not be able to see a future beyond the consultation. This may be particularly evident if the patient has a severe mental illness such as psychosis with nihilistic delusions or command hallucinations where suicidal risk is identified, or if the patient presents as passive about their suicidal thoughts. In such cases, the condition should be considered as acute illness requiring urgent attention: compassion and care may need to be accompanied by a more direct clinical approach, possibly involving the use of the Mental Health Act and admission to hospital. The Bank of Hope can be introduced once the severe and imminent risk has passed.

\section{Conclusions}

The more information the clinician has about the patient's suicidal thoughts, the greater the chance to intervene appropriately, helping the patient to resist acting on these thoughts. This article has outlined the most important aspects of suicide mitigation, a pragmatic approach to preventing suicide. (Box 4). It highlights the essential components of a safe response to a patient experiencing suicidal thoughts and the collaborative creation of a safety plan. We strongly

\section{B0X 4 Key learning}

- The quality of the therapeutic relationship makes it possible for the patient to disclose suicidal thoughts

- Do not be frightened to ask your patient whether they have suicidal thoughts - this is the first step in reducing their risk of completing suicide

- All suicidal thoughts, however 'minor', require a response that needs to be compassionate, proportionate and timely

- Document the date, time and important factors in the history and examination of the suicidal individual: 'If you did not document it then you did not ask it...'

\section{Extremely important}

Not all parts of an individual's presentation are of equal weight when assessing risk. Clinical factors in their history and mental state examination are most important when assessing and responding to suicide risk. Suicidal thoughts/plans, loss of hope and overwhelming distress need compassion, diligent identification of risk, instillation of hope, and a robust safety plan.

\section{BOX 5 Further training}

Connecting with People Emotional Resilience and Suicide Awareness training

A series of peer-reviewed and independently evaluated 2-hour modules, ideally suited to CPD sessions. Participants will be able to develop a compassionate approach suitable for a demanding and time-pressured environment. At the end of the modules, participants will be able to use the clinical resources to enhance their assessment and response to a suicidal patient. They will be able to undertake a safe triage and referral if appropriate, reduce their patients' distress, and collaboratively create a safety plan to increase their patients' resilience to suicidal thoughts (www. connectingwithpeople.org)

\section{STORM training}

STORM $^{\circledR}$ is a well-established and academically evaluated skills-based training package that concentrates on the micro-skills of assessment and management of suicide risk. Through a process of practice and appraisal, staff enhance their skills feeling more able to assess a person considered to be at risk of suicide and to confidently manage the immediate crisis (www. stormskillstraining.co.uk)

\section{ASIST Training}

2-day suicide skills intervention training; prior medical training is not required (www.livingworks.net)

endorse specialist awareness and skills training, as nothing can ever replace the opportunity of developing knowledge, skills and confidence. As well as learning necessary skills, clinicians will be more able to manage real-life scenarios. Box 5 lists some of the training courses available in the UK and the USA. In addition, we urge clinicians to seek both peer support and supervision to discuss patients experiencing suicidal thoughts. Such patients have complex needs and can make heavy emotional demands on professional healthcare staff.

\section{References}

Cole-King A, Lepping P (2010) Suicide mitigation: time for a more realistic approach. British Journal of General Practice 60: 3-4.

Cole-King A, Green G, Peake-Jones G, et al (2011) Suicide mitigation. InnovAiT 4: 288-95.

Cole-King A, Parker V, Williams H, et al (2013) Suicide prevention: are we doing enough? Advances in Psychiatric Treatment 19: 284-91.

Fleischmann A, Bertolote JM, Wasserman D, et al (2008) Effectiveness of brief intervention and contact for suicide attempters: a randomised control trial in five countries. Bulletin of the World Health Organisation 86: 703-9.

Hawton K, van Heeringen K (2009) Suicide. Lancet 373: 1372-81. 
Henden, J (2008) Preventing Suicide: The Solution Focused Approach. John Wiley \& Sons.

Hines K, Cole-King A, Blaustein M (2013) Hey kid, are you OK? A story of suicide survived. Advances in Psychiatric Treatment 19: 292-4 [open access].

Jobes DA, Comtois KA, Brenner L, et al (2011) Clinical trial feasibility studies of the Collaborative Assessment and Management of Suicidality. In International Handbook of Suicide Prevention (eds R O'Connor, S Platt, J Gordon): 383-400. Wiley-Blackwell.

Larson EB, Yao Y (2005) Clinical empathy as emotional labour in the patient-physician relationship. JAMA 293: 1100-6.

Malone KM, Szanto K, Corbitt EM, et al (1995) Clinical assessment versus research methods in the assessment of suicidal behaviour. American Journal of Psychiatry 152: 1601-7.

McLean J, Maxwell M, Platt S, et al (2008) Risk and Protective Factors for Suicide and Suicidal Behaviour: A Literature Review. Scottish Government.
National Confidential Inquiry into Suicide and Homicide by People with Mental IIIness (2010) Annual Report: England and Wales July 2010. University of Manchester.

Nock MK, Borges G, Bromet EJ, et al (2008) Cross-national prevalence and risk factors for suicidal ideation, plans and attempts. British Journal of Psychiatry 192: 98-105.

Royal College of Psychiatrists (2010) Self-Harm, Suicide and Risk: Helping People who Self-Harm (College Report CR158). Royal College of Psychiatrists.

Taylor TL, Hawton K, Fortune S, et al (2009) Attitudes towards clinical services among people who self-harm: systematic review. British Journal of Psychiatry 194: 104-10.

Thompson AR, Powis J, Carradice A (2008) Community psychiatric nurses' experience of working with people who engage in deliberate self-harm. International Journal of Mental Health Nursing 17: 153-61.

Watts D, Morgan G (1994) Malignant alienation: dangers for patients who are hard to like. British Journal of Psychiatry 164: 11-5.

\section{EMI}

Match the numbered statements $(1,2,3, \ldots)$ with a suitable response from the lettered options (a, $b, c, \ldots)$. Each option may be used once, more than once, or not at all and more than one option may be suitable for each statement.

\section{Theme: Assessing a patient following self-} harm

You have been asked to see a 24-year-old man who has been treated in the accident and emergency department (A\&E) for a suspected overdose of sleeping tablets. He tells you that he mistakenly took more than the dose stated on the pack because he 'wasn't thinking straight' - he was tired owing to lack of sleep and just wanted to get one good night. He denies that there is anything wrong with him, but appears restless and unable to make eye contact.

1 What is the minimum information that the $A \& E$ doctor should have established?

2 You suspect that the patient is in more distress than he is admitting to, and feel that this needs further investigation. What approach would you take to encourage him to talk about his thoughts and feelings?

3 You suspect that the intention of taking the overdose was to complete suicide. What do you need to ask for a comprehensive suicide risk assessment?

4 Which parts of his history will be the most important factors when establishing the longerterm management of this young man?

Options

a A pragmatic approach: the patient is unwilling to be helped; offer no further input

b A pragmatic approach: the patient is unwilling to be fully assessed, but offer information about third-sector support and inform the GP

c A compassionate approach to positively engage the patient and a comprehensive assessment, including instilling hope and aiming to increase his resilience to further suicidal thoughts

$d$ Elicit risk factors and be guided by presence or absence of those e Ask the patient's family for information regarding his mood and behaviour before the suspected overdose

$f$ Suicide intent now and before the overdose frequency of suicidal thoughts; plan before the overdose; feelings of hopelessness; risk factors

g Suicide intent now and before the overdose previous self-harm; feelings of hopelessness; protective factors and coping strategies regarding his ability not to act on recurrent suicidal thoughts/thoughts of self-harm, and current support 